\title{
Dysregulated epidermal growth factor and tumor growth factor-beta receptor signaling through GFAP-ACTA2 protein interaction in liver fibrosis
}

\author{
Sobia Hassan ${ }^{1}$, Zil-e-Rubab², \\ Hussain Shah ${ }^{3}$, Summayya Shawana
}

\begin{abstract}
Objective: Viral hepatitis is associated with high morbidity and mortality. Identification of biological pathways involved in hepatic fibrosis resulting from chronic hepatitis $C$ are essential for better management of patients. Constructing the $\mathrm{HCV}$-human protein interaction network through bioinformatics may enable us to discover diagnostic biological pathways. We investigated to identify dysregulated pathways and gene enrichment based on actin alpha 2 (ACTA2) and glial fibrillar acidic protein (GFAP) interaction network analysis in hepatic fibrosis.

Methods: This is an in-silico study conducted at Ziauddin University from March,2019 to September 2019. Enrichment and protein-protein interaction (PPI) network analysis of the identified proteins: GFAP and ACTA2 along with their mapped gene data sets was performed using FunRich version 3.1.3.

Results: Biological pathway grouping showed enrichment of proteins $(85.7 \%)$ in signalling pathway by epidermal growth factor receptor (EGFR) and Tumor growth factor (TGF)-beta Receptor followed by signaling by PDGF, FGFR and NGF (71.4\%) ( $\mathrm{p}<0.001)$. SRC, PRKACA, PRKCA and PRKCD were enriched in both EGFR and TGF-beta Signalling pathways.

Conclusion: EGFR and TGF-beta signalling pathways were enriched in liver fibrosis. SRC, PRKACA, PRKCA and PRKCD were enriched and differentially expressed in both EGFR and TGF-beta signalling pathways
\end{abstract}

KEYWORDS: ACTA2, GFAP, Liver fibrosis, Signalling by EGFR, TGF-beta receptor Signalling.

doi: https://doi.org/10.12669/pjms.36.4.1845

How to cite this:

Hassan S, Zil-e-Rubab, Shah H, Shawana S. Dysregulated epidermal growth factor and tumor growth factor-beta receptor signaling through GFAP-ACTA2 protein interaction in liver fibrosis. Pak J Med Sci. 2020;36(4):782-787. doi: https://doi.org/10.12669/pjms.36.4.1845

This is an Open Access article distributed under the terms of the Creative Commons Attribution License (http://creativecommons.org/licenses/by/3.0), which permits unrestricted use, distribution, and reproduction in any medium, provided the original work is properly cited.

1. Dr. Sobia Hassan, MBBS, M. Phil.

Altamash Institute of Dental Medicine, Karachi, Pakistan.

2. Dr. Zil-e-Rubab, MBBS, M. Phil, PhD.

Ziauddin University Clifton Campus, Karachi, Pakistan.

3. Mr. Hussain Shah,

Department of Chemical \& Biomolecular Engineering,

University of Melbourne, Australia.

4. Dr. Summayya Shawana, MBBs, M. Phil.

Bahria University Medical \& Dental College, Karachi, Pakistan.

Correspondence:

Dr. Zil-e-Rubab, MBBS, M. Phil, PhD.

Cancer Biology \& Therapeutics, Harvard Medical School

Professor, Biochemistry Department,

Ziauddin University Clifton Campus,

Karachi, Pakistan.

E-mail: zile.rubab@zu.edu.pk

zile_rubab@alumni.harvard.edu

* Received for Publication:

October 20, 2019

* Revision Received:

* Revision Accepted:

\section{INTRODUCTION}

Hepatic fibrosis is the basic damage resulting from chronic hepatitis $\mathrm{C}(\mathrm{CHC})$ which is one of the prime health challenges. ${ }^{1}$ The ultramicroscopic changes occurring in hepatic fibrosis include activation of hepatic stellate cells (HSCs) which is triggered by injury to hepatocytes. ${ }^{2}$ The excessive secretion of collagen by activated HSCs induces hyperplasia and deposition of extracellular matrix (ECM), which ultimately leads to liver fibrosis and cirrhosis. ${ }^{3,4}$ When HSCs trans differentiate into proliferative, and contractile myofibroblasts, they express certain mesenchymal markers like alpha smooth muscle actin, encoded by Actin alpha 2ACTA2 gene which is an isoform of the vascular smooth muscle actin and is expressed in all stages 
and grades of $\mathrm{CHC}^{5}$ The expression of contractile filaments, Alpha smooth muscle actin (a SMA), was identified in stellate cells forming a basis of using smooth muscle actin as an immunohistochemical marker, which detects HSCs activation and a useful marker for early diagnosis of hepatic fibrosis. ${ }^{6}$ In addition to ACTA2, studies have shown that there is augmented expression of Glial Fibrillary Acidic -GFAP-positive HSCs in early stages of hepatic fibrosis. ${ }^{7}$ The GFAP gene encodes a class III intermediate filament protein expressed specifically in astrocytes of the central nervous system and their transformation capacity is well conserved. ${ }^{8}$ A study in rodents reported the expression of GFAP with an increased expression in the acute response to injury in the rat, and a decreased in the chronic one. ${ }^{9}$ It is reported that GFAP could represent a more useful marker than Alpha smooth muscle actin (a-SMA) of early HSCs activation and may be an early indicator of hepatic fibrogenesis. Our study done in 2014 revealed strong association of GFAP with the gold standard immunohistochemical marker, ACTA2 suggesting that GFAP could be a useful indicator of early HSCs activation in CHC patients. ${ }^{10}$ The GFAP positive hepatic cells may be antecedents of the HSCs detected by ACTA2 or they may denote a diverse subpopulation. ${ }^{11,12}$

Most common cause of hepatocellular carcinoma (HCC) in our country is viral hepatitis. ${ }^{13}$ It is vital that degree of cirrhosis is established by the clinician and risk factors for HCC are identified. Bioinformatics has enabled us to discover diagnostic biomarkers and to plan treatment modalities. ${ }^{14}$ In light of above facts, the purpose of this study is to identify dysregulated pathways and gene enrichment based on ACTA2 and GFAP interaction network analysis in hepatic fibrosis.

\section{METHODS}

This is an in-silico study. GFAP and ACTA2 were obtained by immunohistochemistry in previous study ${ }^{9}$ by one of the authors which was approved by the Ethical Review Committee (Ref. Code: 1601119ZRBIO) of Ziauddin University. The study was done from March-September 2019.

In this study, the gene expression and interaction of GFAP and ACTA2 were analysed in silico. Immunoexpression of GFAP revealed substantial association with ACTA2 (a-SMA) in previous study concluding inverse relationship of GFAP with progression of fibrosis. Hence, GFAP could be characterized as useful marker for early hepatic stellate cells activation.
Bioinformatics analysis: Enrichment and proteinprotein interaction (PPI) network analysis of the identified proteins: GFAP and ACTA2 along with their mapped gene data sets was performed using FunRich: Functional Enrichment analysis tool version 3.1.3 released on March 2017 http:/ / www.funrich. org $^{14}$ The enriched and depleted proteins were identified by calculating fold change for biological pathways, protein domains and site of expressions. Interaction network analysis: In FunRich software hypergeometric test, $\mathrm{BH}$ and Bonferroni test were applied. Normal and Overrepresented and gene ontology (GO) functional categories, significant interactions and pathways associated with datasets were identified by using the hypergeometric test and $\mathrm{p}$-value correction with the $\mathrm{BH}$ and Bonferroni tests. Statistical cut-off of enrichment analyses was kept as default with a $\mathrm{p}=$ value $<0.05$ after Bonferroni correction.

\section{RESULTS}

Protein-Protein Interaction (PPI) Analysis of GFAP and ACTA2: The protein-protein interaction network visualization and its analysis of GFAP and ACTA2 was performed using FunRich database. The interaction network included the biological pathway enrichment of defined proteins. The PPI network was among differentially regulated interacting proteins of potential retrieved from interaction of GFAP and ACTA2 in Fig.1. Among selected GFAP and ACTA2 interacting 44 protein genes, all had interactions with each other as shown in Fig.1.The gene mapping of GFAP and ACTA2

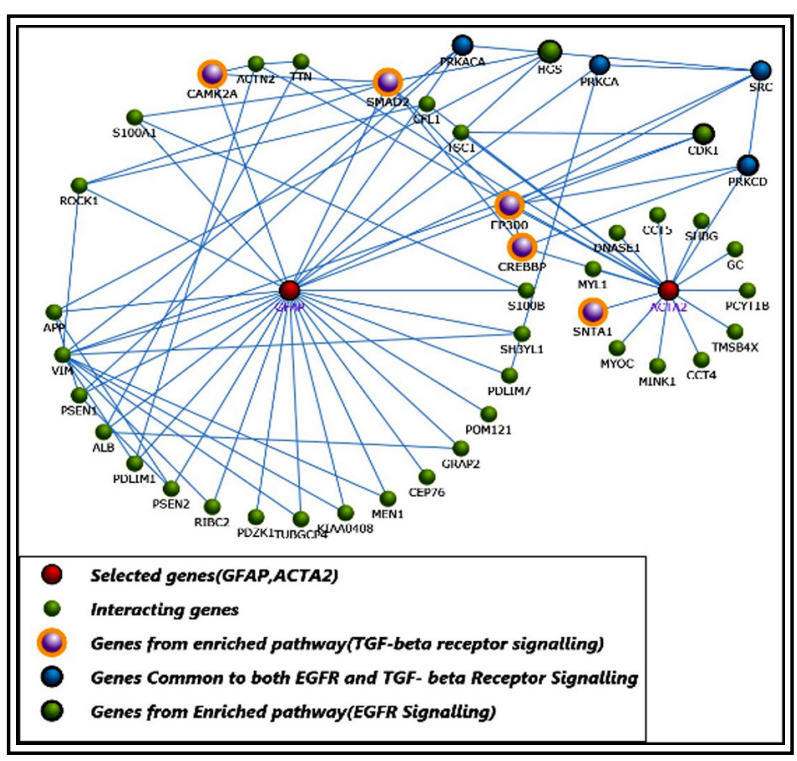

Fig.1: Protein-Protein interaction (PPI) Network of GFAP and ACTA2. 
Table-I: Gene Mapping and Biological Pathways Enriched in Interaction of GFAP and ACTA2 shown in Fig.1.

\begin{tabular}{|c|c|c|c|c|c|c|}
\hline $\begin{array}{l}\text { Gene } \\
\text { symbol }\end{array}$ & Protein Name & $\begin{array}{l}\text { Chrom- } \\
\text { osome }\end{array}$ & Map location & $\begin{array}{l}\text { Interacting Genes with } \\
\text { GFAP and ACTA } 2\end{array}$ & Biological Pathway & p-value \\
\hline PRKCD & $\begin{array}{l}\text { Protein kinase } \\
\text { C, delta }\end{array}$ & 3 & $3 p 21.31$ & $\begin{array}{l}\text { CREBBP; PRKCA; } \\
\text { EP300; CDK1; PRKACA }\end{array}$ & $\begin{array}{l}\text { Retinoic acid } \\
\text { receptors-mediated } \\
\text { signaling }\end{array}$ & $p=0.009$ \\
\hline HGS & $\begin{array}{l}\text { Hepatocyte } \\
\text { growth factor- } \\
\text { regulated } \\
\text { tyrosine kinase } \\
\text { substrate }\end{array}$ & 17 & $17 q 25$ & $\begin{array}{l}\text { PRKCD; PRKCA; SRC; } \\
\text { VIM; SMAD2; }\end{array}$ & Alpha6Beta4Integrin & $p=0.01$ \\
\hline PRKCA & $\begin{array}{l}\text { protein kinase } \\
\mathrm{C} \text {, alpha }\end{array}$ & 17 & $17 q 22-q 23.2$ & $\begin{array}{l}\text { PRKCD; PRKCA; SRC; } \\
\text { PRKACA; ROCK1 }\end{array}$ & $\begin{array}{l}\text { Thromboxane A2 } \\
\text { receptor signaling }\end{array}$ & $p=0.017$ \\
\hline $\mathrm{RC}$ & $\begin{array}{l}\text { SRC proto- } \\
\text { oncogene, Non- } \\
\text { receptor tyrosine } \\
\text { kinase }\end{array}$ & 20 & 20q12-q13 & $\begin{array}{l}\text { PRKCD; PRKCA; SRC; } \\
\text { CDK1; PRKACA; } \\
\text { PSEN1; PSEN2 }\end{array}$ & Signalling by NGF & $p=0.018$ \\
\hline CDK1 & $\begin{array}{l}\text { Cyclin- } \\
\text { dependent } \\
\text { kinase } 1\end{array}$ & 10 & $10 \mathrm{q} 21.1$ & $\begin{array}{l}\text { PRKCD; HGS; PRKCA; } \\
\text { SRC; CDK1; PRKACA }\end{array}$ & Signaling by EGFR & $\mathrm{p}=0.023$ \\
\hline PRKACA & $\begin{array}{l}\text { Protein } \\
\text { kinase, cAMP- } \\
\text { dependent, } \\
\text { catalytic, Alpha }\end{array}$ & 19 & 19p13.1 & $\begin{array}{l}\text { CREBBP; PRKCD; } \\
\text { PRKCA; EP300; SRC; } \\
\text { VIM; PRAKCA; APP; } \\
\text { SNTA1 }\end{array}$ & $\begin{array}{l}\text { TNF receptor signaling } \\
\text { pathway }\end{array}$ & $p=0.043$ \\
\hline GFAP & $\begin{array}{l}\text { Glial fibrillary } \\
\text { acidic protein }\end{array}$ & 17 & $17 q 21$ & $\begin{array}{l}\text { CREBBP; PRKCD; } \\
\text { PRKCA; EP300; SRC; } \\
\text { PRKACA; SMAD2; } \\
\text { SNTA1; CAMK2A }\end{array}$ & $\begin{array}{l}\text { TGF-beta receptor } \\
\text { signaling }\end{array}$ & $p=0.051$ \\
\hline ACTA2 & $\begin{array}{l}\text { Actin, alpha 2, } \\
\text { smooth muscle, } \\
\text { Aorta }\end{array}$ & 10 & $10 \mathrm{q} 23.3$ & $\begin{array}{l}\text { CREBBP; PRKCD; } \\
\text { PRKCA; EP300; SRC; } \\
\text { PRKACA; SMAD2; } \\
\text { SNTA1; CAMK2A }\end{array}$ & $\begin{array}{l}\text { Regulation of nuclear } \\
\text { SMAD2/3 signaling }\end{array}$ & $\mathrm{p}=0.051$ \\
\hline CREBBP & $\begin{array}{l}\text { CREB binding } \\
\text { protein }\end{array}$ & 16 & $16 \mathrm{p} 13.3$ & $\begin{array}{l}\text { CREBBP; PRKCD; } \\
\text { PRKCA; EP300; SRC; } \\
\text { PRKACA; SMAD2; } \\
\text { SNTA1; CAMK2A }\end{array}$ & $\begin{array}{l}\text { Regulation of } \\
\text { cytoplasmic and } \\
\text { nuclear SMAD2/3 } \\
\text { signaling }\end{array}$ & $p=0.051$ \\
\hline PRKCD & $\begin{array}{l}\text { Protein kinase } \\
\text { C, Delta }\end{array}$ & 3 & $3 p 21.31$ & $\begin{array}{l}\text { CREBBP; PRKCD; } \\
\text { PRKCA; EP300; SRC; } \\
\text { PRKACA; SMAD2; } \\
\text { SNTA1; CAMK2A }\end{array}$ & ALK1 signaling events & $p=0.076$ \\
\hline PRKCA & $\begin{array}{l}\text { Protein kinase } \\
\text { C, Alpha }\end{array}$ & 17 & $17 q 22-q 23.2$ & $\begin{array}{l}\text { CREBBP; PRKCD; } \\
\text { PRKCA; EP300; SRC; } \\
\text { PRKACA; SMAD2; } \\
\text { SNTA1; CAMK2A }\end{array}$ & ALK1 pathway & $\mathrm{p}=0.082$ \\
\hline
\end{tabular}

interacting proteins with their chromosomal location was shown in Table-I. The enzymes represented the major category mapped along with protein kinase $\mathrm{C}$ and proto-oncogenes of tyrosine kinase. The leading biological pathways associated with these interacting proteins were signalling by EGFR and TGF-beta receptor signalling as depicted in Table-I.
The proteins enriched in Signalling by EGFR Pathway were HGS, CDK1, PRKCA, SRC, PRKCD and PRKACA. Likewise, Protein-Protein interaction (PPI) Network of GFAP and ACTA2 enriched in TGF-beta receptor Signalling were PRKACA, PRKCA, CAMK2A, SRC, SMAD2, PRKCD, CREBB and SNTA1. It is worth mentioning that SRC, PRKACA, PRKCA and PRKCD were 
Table-II: Heat Map Showing Differentially Expressed Proteins \& their Pathways Interacting with Genes enriched in Signalling by EGFR Pathway and TGF-beta receptor signaling pathway shown in Fig 1.

\begin{tabular}{|c|c|c|c|c|c|c|c|}
\hline Biological pathway & $\begin{array}{l}\text { Fold } \\
\text { enrichment }\end{array}$ & $\begin{array}{l}\text { P-value } \\
\text { (Hyperg- } \\
\text { eometric } \\
\text { test) }\end{array}$ & $\begin{array}{l}\text { Genes mapped } \\
\text { (Signalling } \\
\text { by EGFR } \\
\text { Pathway) }\end{array}$ & $\begin{array}{l}\text { Biological } \\
\text { pathway }\end{array}$ & $\begin{array}{l}\text { Fold } \\
\text { enrich- } \\
\text { ment }\end{array}$ & $\begin{array}{l}\text { P-value } \\
\text { (Hyper- } \\
\text { geometric } \\
\text { test) }\end{array}$ & $\begin{array}{l}\text { Genes mapped } \\
\text { (TGF-beta receptor } \\
\text { signaling Pathway) }\end{array}$ \\
\hline $\begin{array}{l}\text { EGF receptor } \\
\text { (ErbB1) signaling } \\
\text { pathway }\end{array}$ & 4.894911 & $1.47 \mathrm{E}-05$ & $\begin{array}{l}\text { PRKCD; } \\
\text { HGS; } \\
\text { PRKCA; } \\
\text { SRC; CDK1; } \\
\text { PRKACA; } \\
\text { ACTA2; }\end{array}$ & & & & $\begin{array}{l}\text { CREBBP; } \\
\text { PRKCD; PRKCA; } \\
\text { CAMK2A; }\end{array}$ \\
\hline $\begin{array}{l}\text { EGFR-dependent } \\
\text { Endothelin } \\
\text { signaling events }\end{array}$ & 4.891105 & 1.47E-05 & $\begin{array}{l}\text { PRKCD; } \\
\text { HGS; } \\
\text { PRKCA; } \\
\text { SRC; CDK1; } \\
\text { PRKACA; } \\
\text { ACTA2; }\end{array}$ & $\begin{array}{l}\text { Regulation of } \\
\text { cytoplasmic } \\
\text { and nuclear } \\
\text { SMAD2/3 } \\
\text { signaling }\end{array}$ & 20.62231 & $1.32 \mathrm{E}-12$ & $\begin{array}{l}\text { EP300; SRC; } \\
\text { PRKACA; } \\
\text { SMAD2; SNTA1; }\end{array}$ \\
\hline $\begin{array}{l}\text { Signaling events } \\
\text { mediated by } \\
\text { Hepatocyte } \\
\text { Growth Factor } \\
\text { Receptor (c-Met) }\end{array}$ & 4.875939 & $1.51 \mathrm{E}-05$ & $\begin{array}{l}\text { PRKCD; } \\
\text { HGS; } \\
\text { PRKCA; } \\
\text { SRC; CDK1; } \\
\text { PRKACA; } \\
\text { ACTA2; }\end{array}$ & & & & \\
\hline $\begin{array}{l}\text { Signaling by } \\
\text { EGFR }\end{array}$ & 55.02213 & 8.48E-11 & $\begin{array}{l}\text { PRKCD; } \\
\text { HGS; } \\
\text { PRKCA; } \\
\text { SRC; CDK1; } \\
\text { PRKACA; }\end{array}$ & $\begin{array}{l}\text { TGF-beta } \\
\text { receptor } \\
\text { signaling }\end{array}$ & 20.62231 & $1.32 \mathrm{E}-12$ & $\begin{array}{l}\text { CREBBP; PRKCD; } \\
\text { PRKCA; EP300; } \\
\text { SRC; PRKACA; } \\
\text { SMAD2; SNTA1; } \\
\text { CAMK2A; }\end{array}$ \\
\hline $\begin{array}{l}\text { Signal } \\
\text { Transduction }\end{array}$ & 4.464134 & 0.000291 & $\begin{array}{l}\text { PRKCD; } \\
\text { HGS; } \\
\text { PRKCA; } \\
\text { SRC; CDK1; } \\
\text { PRKACA; }\end{array}$ & $\begin{array}{l}\text { Signaling } \\
\text { events } \\
\text { mediated by } \\
\text { VEGFR1 and } \\
\text { VEGFR2 }\end{array}$ & 4.864626 & $6.41 \mathrm{E}-07$ & $\begin{array}{l}\text { CREBBP; PRKCD; } \\
\text { PRKCA; EP300; } \\
\text { SRC; PRKACA; } \\
\text { SMAD2; SNTA1; } \\
\text { CAMK2A; }\end{array}$ \\
\hline $\begin{array}{l}\text { Signaling by } \\
\text { PDGF }\end{array}$ & 57.6263 & 5.31E-09 & $\begin{array}{l}\text { PRKCD; } \\
\text { PRKCA; } \\
\text { SRC; CDK1; } \\
\text { PRKACA; }\end{array}$ & $\begin{array}{l}\text { EGFR- } \\
\text { dependent } \\
\text { Endothelin } \\
\text { signaling } \\
\text { events }\end{array}$ & 4.891105 & 6.10E-07 & $\begin{array}{l}\text { CREBBP; PRKCD; } \\
\text { PRKCA; EP300; } \\
\text { SRC; PRKACA; } \\
\text { SMAD2; SNTA1; } \\
\text { CAMK2A; }\end{array}$ \\
\hline $\begin{array}{l}\text { Signaling by } \\
\text { FGFR }\end{array}$ & 47.31531 & $1.45 \mathrm{E}-08$ & $\begin{array}{l}\text { PRKCD; } \\
\text { PRKCA; } \\
\text { SRC; CDK1; } \\
\text { PRKACA; }\end{array}$ & $\begin{array}{l}\text { p38 MAPK } \\
\text { signaling } \\
\text { pathway }\end{array}$ & 25.89165 & $6.78 \mathrm{E}-10$ & $\begin{array}{l}\text { CREBBP; PRKCD; } \\
\text { PRKCA; EP300; } \\
\text { SRC; PRKACA; } \\
\text { SNTA1; }\end{array}$ \\
\hline $\begin{array}{l}\text { TGF-beta } \\
\text { receptor } \\
\text { signaling }\end{array}$ & 11.79678 & 0.000169 & $\begin{array}{l}\text { PRKCD; } \\
\text { PRKCA; SRC; } \\
\text { PRKACA; }\end{array}$ & $\begin{array}{l}\text { Role of } \\
\text { Calcineurin- } \\
\text { dependent } \\
\text { NFAT } \\
\text { signaling in } \\
\text { lymphocytes }\end{array}$ & 36.81247 & 8.49E-08 & $\begin{array}{l}\text { CREBBP; PRKCD; } \\
\text { PRKCA; EP300; } \\
\text { PRKACA; }\end{array}$ \\
\hline
\end{tabular}

enriched in both EGFR and TGF-beta Signalling pathways as shown in Fig.1.

In liver fibrosis, there were divergent proteome repertoires regarding EGFR and TGF beta receptor signalling. Superimposed bar chart depicted fold comparison of the differential expression of biological pathway proteins involved in EGFR Signalling (6) against TGF Beta Receptor Signalling 


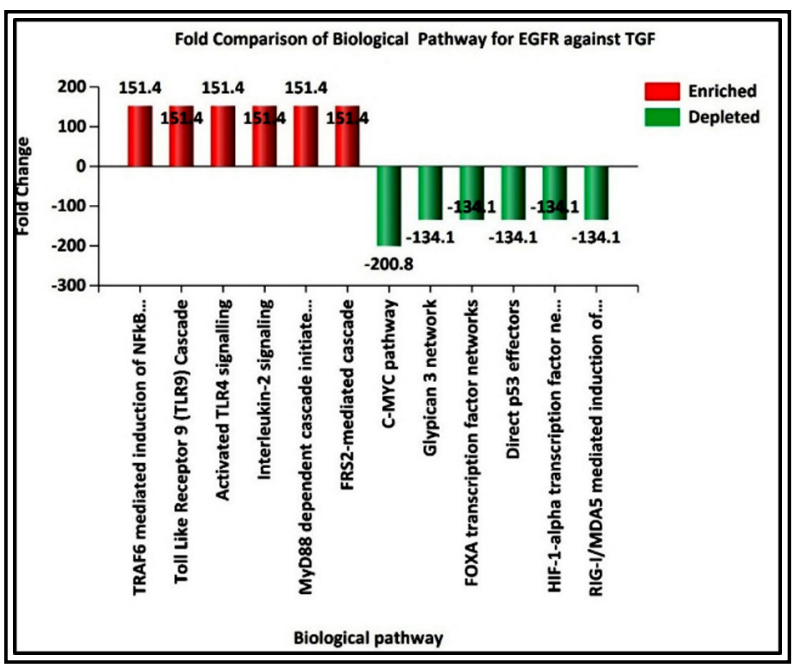

Fig.2: Fold Comparison for Biological Pathway of proteins involved in EGFR Signalling (6) against TGF Beta Receptor.

(9). The proteins in related to EGFR signalling pathways were enriched up to 150 fold while proteins in EGFR signalling were depleted more than 130 fold (Fig.2).

Differential Expression Genes/Proteins and their Pathways: In Table-II, deep red boxes showed significant enriched pathways were Signaling by EGFR with fold enrichment of more than 2 folds and p-value: 1.51E-05 and TGF-beta receptor signalling with fold enrichment of more than 10 folds and $p$ value: 1.32E-12. The common genes related to these pathways are PRKCD; PRKCA; SRC; CDK1; PRKACA, CREBBP; PRKCD; PRKCA; CAMK2A; EP300; SRC; PRKACA; SMAD2; SNTA1 are shown in the same Table-II.

\section{DISCUSSION}

Fibrosis is a characteristic feature of end-stage liver disease and it constitutes a predominant cause of global rise in mortality and morbidity. ${ }^{1}$ Chronic hepatic injury irrespective of cause is characterized by hepatic stellate cells (HSCs) activation, proliferation, and migration within liver tissue. ${ }^{15}$ These HSCs express various mesenchymal markers upon activation ${ }^{6}$. Expression of two such markers ACTA2 and GFAP has been demonstrated in our previous study by using immunohistochemistry. ${ }^{9}$ The management of hepatic fibrosis still remains a challenge therefore the identification of these proteins and their interacting pathways involved is critical in facilitating early diagnosis and designing target therapeutic modalities. ${ }^{16,17}$

The Pathway analyses play a vital role understanding biological mechanisms underlying various disease processes. Therefore, they can help in identifying more potent biomarkers using dysregulated pathways. ${ }^{13}$ We used a network-based method to ascertain the dysregulated pathways elaborated in hepatitis $C$ which may build new insights into pathogenesis of liver fibrosis. ${ }^{18}$ TGF- $\beta /$ Smad signaling pathway is known to be one of the key fibrogenic and inflammatory pathways in the liver. ${ }^{19}$ TGF- $\beta 1$ have been implicated in the process of activating HSCs with the magnitude of fibrosis being in proportion to increase in TGF $\beta$ levels. Studies have shown that ACTA2 is associated with TGF $\beta$ pathway that enhances contractile properties of HSCs leading to fibrosis. ${ }^{20}$ The results of our study show that biologic pathways associated with GFAP and ACTA2 were signaled by TGF $\beta$ receptor signaling which is consistent with the previous studies. On the basis of close interaction of proteins, we used PPI networks to identify diseasespecific networks. Our study showed a number of proteins enriched in TGFR signaling primarily involving PRKACA, PRKCA, CAMK2A, SRC, SMAD2, PRKCD, CREBB and SNTA1. Moreover, functional enrichment analysis of GFAP and ACTA2 interacting proteins showed $85.7 \%$ enrichment of proteins in signaling pathways of EGFR. This led to identification of another pathway, the epidermal growth factor receptor (EGFR or ErbB1) signaling system, which seems to be strongly associated with the interacting proteins GFAP and ACTA2. This finding may be due to the facilitation of crosstalk between signaling pathways by EGFR, resulting in release of various mediators of inflammation and repair. ${ }^{11}$ The EGFR signaling is reported to be a key element in not only fibrosis but also the proliferation of fibrotic liver injury to neoplastic transformation.

The study by Yang et al. has shown that EGFs can stimulate proliferation of hepatic stellate cells, which is the primary effector cell, orchestrating the deposition of extracellular matrix (ECM) in fibrotic liver. ${ }^{16}$ EGFR showed signaling enrichment of proteins similar to those in TGFR, including PRKACA, PRKCA, SRC, SMAD2 and PRKCD. Protein kinase $C(P K C)$ is a group of calcium dependent proteins which regulate embryonic development. Various members of this PKC family have been implicated in progression of cell cycle, apoptosis and differentiation. ${ }^{21}$ Protein kinase A family of proteins is activated in response to $G$ coupled protein receptors ${ }^{22}$ while PRKCD plays a key role in autophagy suppression which is achieved by the process of phosphorylation of $A K T$ which further activates mTOR, specific for fibrolamellar carcinoma. ${ }^{23}$ In current study, activity of c-SRC 
decreases with progressive liver fibrogenesis and hepatic stellate cell (HSC) activation. This finding is consistent with literature which reports that inhibition of SRC Kinase promotes HCV replication. ${ }^{24}$ The oncogenic properties of $S R C$ family kinases have been reported with various studies upon role of $S R C$ as target therapy in the treatment of idiopathic pulmonary fibrosis, systemic sclerosis and glioblastoma. However, its role in liver fibrosis progression is not yet understood. ${ }^{25} \mathrm{SRC}$ along with PRKACA, PRKCA and PRKCD must be further explored to establish their role in target therapy of hepatic fibrosis in chronic hepatitis.

\section{CONCLUSION}

In this analysis, many perilous pathways and genes were identified based on protein-protein interaction of network GFAP and ACTA2. EGFR and TGF-beta Receptor Signalling pathways were found to be enriched in liver fibrosis through Protein Interaction studies. SRC, PRKACA, PRKCA and $P R K C D$ were enriched and differentially expressed in both EGFR and TGF-beta Signalling pathways. These signalling pathways and related proteins are the potential targets for new therapeutic agents to combat liver fibrosis resulting from chronic hepatitis $\mathrm{C}$.

Conflicts of interest: The authors declare no conflict of interest with regard to this work

\section{Grant Support \& Financial Disclosures: None.}

\section{REFERENCES}

1. Shay JES, Hamilton JP. Hepatic fibrosis: Avenues of investigation and clinical implications. Clin Liver Dis. 2018;11(5):111-114. doi: $10.1002 /$ cld.702

2. Lee YA, Wallace MC, Friedman SL. Pathobiology of liver fibrosis: a translational success story. Gut. 2015;64:830-841. doi: 10.1136/ gutjnl-2014-306842

3. Davidson M, Song KH, Mu Lee H, Llewellyn J, Du Y, Baker B, et al. Engineered fibrous networks to investigate the influence of fiber mechanics on myofibroblast differentiation. ACS Biomater Sci Eng. 2019;5(8):3899-3908 doi: 10.1021/acsbiomaterials.8b01276

4. Higashi T, Friedman SL, Hoshida Y. Hepatic stellate cells as key target in liver fibrosis. Adv Drug Deliv Rev. 2017;121:27-42. doi 10.1016/j.addr.05.007

5. Sandulescu L, Rogoveanu I, Ciurea T, Comanescu MV, Streba CT, Ionescu AG, et al. Immunohistochemical study of stellate cells in patients with chronic viral hepatitis C genotype. Rom J Morphol Embryol. 2011;52:137-143.

6. Sohier Zakaria MY, Moussa M, Akl M, El-Ahwany E, ElRaziky M, Mostafa O, et al. Value of a-smooth muscle actin and glial fibrillary acidic protein in predicting early hepatic fibrosis in chronic hepatitis C virus infection. Arch Med Sci. 2010;6(3):356-366. doi: 10.5114/ aoms.2010.14255

7. Eun K, Hwang SU, Jeon HM, Hyun SH, Kim H. Comparative Analysis of Human, Mouse, and Pig Glial Fibrillary Acidic Protein Gene Structures. Anim Biotechnol. 2016;27(2):126-132

8. Bai X, Saab AS, Huang W, Hoberg IK, Kirchhoff F, Scheller A. Genetic background affects human glial fibrillary acidic protein promoter activity. PloS One. 2013;8(6):e66873. doi:10.1371/journal.pone.0066873
9. Hassan S, Syed S, Kehar SI. Glial fibrillary acidic protein (GFAP) as a mesenchymal marker of early hepatic stellate cells activation in liver fibrosis in chronic hepatitis C infection. Pak J Med Sci. 2014;30(5):1027-1032. doi: 10.12669/pjms.305.5534

10. Zhou L, Shang M, Shi M, Zhao L, Lin Z, Chen T, et al. Clonorchis sinensis lysophospholipase inhibits TGF- $\beta 1$-induced expression of pro-fibrogenic genes through attenuating the activations of Smad3, JNK2, and ERK1/2 in hepatic stellate cell line LX-2. Parasitol Res. 2016;115:643-650. doi: 10.1007/s00436-015-4782-7

11. Berasain C, Avila, MA. The EGFR signalling system in the liver: from hepato protection to hepatocarcinogenesis. J Gastroenterol. 2014;49:9-23. doi: 10.1007/s00535-013-0907-x

12. Martel C, Maucort-Boulch D. World-wide relative contribution of hepatitis B and C viruses in hepatocellular carcinoma Hepatobiliary Malignancies. Hepatology. 2015;62(4):1190-1200. doi: 10.1002/hep.27969

13. Zhaozhang Shi, Xia Yu, Xiaoqing Wang. Identification of dysregulated pathways involved in hepatitis $C$ based on network pathway enrichment analysis. Int J Clin Exp Pathol. 2016;9(5):5611-5619.

14. Pathan M, Keerthikumar S, Ang CS, Gangoda L, Quek CY, Williamson, NA, et al. FunRich: An open access standalone functional enrichment and interaction network analysis tool. Proteomics. 2015;15:2597-2601. doi: 10.1002/pmic.201400515

15. Tan Z, Liu Q, Jiang R, Lv L, Shoto SS, Maillet I, et al. Interleukin-33 drives hepatic fibrosis through activation of hepatic stellate cells Cell Mol Immunol. 2018;15(4):388-398. doi: 10.1038/cmi.2016.63

16. Yang HY, Kim KS, Lee YH, Park JH, Kim JH, Lee SY, et al Dendropanax morbifera Ameliorates Thioacetamide-Induced Hepatic Fibrosis via TGF- $\beta 1 /$ Smads Pathways. Int J Biol Sci. 2019;15(4):800-811. doi: 10.7150/ijbs.30356

17. Su TH, Shiau CW, Jao P, Yang NJ, Tai WT, Liu CJ, et al. Src-homology protein tyrosine phosphatase-1 agonist, SC-43, reduces liver fibrosis Sci Rep. 2017;7(1):1728. doi: 10.1038/s41598-017-01572-z.

18. Song Q, Zhao C, Ou S, Meng Z, Kang P, Fan L, et al. Coexpression analysis of differentially expressed genes in hepatitis $C$ virusinduced hepatocellular carcinoma. Mol Med Rep. 2015;11:21-28. doi: 10.3892/mmr.2014.2695

19. Liu H, Dong F, Li G, Niu M, Zhang C, Han $Y$, et al. Liuweiwuling tablets attenuate BDL-induced hepatic fibrosis via modulation of TGF- $\beta /$ Smad and NF-kB signaling pathways. J Ethnopharmacol. 2018;210:232-241. doi: 10.1016/j.jep.2017.08.029

20. Hu HH, Chen DQ, Wang YN, Feng YL, Cao G, Vaziri ND, et al. New insights into TGF- $\beta$ /Smad signaling in tissue fibrosis. Chem Biol Interact. 2018;292:76-83. doi: 10.1016/j.cbi.2018.07.008

21. Yang QE, Ozawa M, Zhang $\mathrm{K}$, Johnson SE, Ealy AD. The requirement for protein kinase $\mathrm{C}$ delta (PRKCD) during preimplantation bovine embryo development. Reprod Fertil Dev. 2016;28(4):482-490. doi: 10.1071/RD14160

22. Graham RP, Jin L, Knutson DL, Kloft-Nelson SM, Greipp PT, Waldburger N, et al. DNAJB1-PRKACA is one of its subunit is encoded by PRKACA. Mod Pathol. 2015;28(6):822-829. doi: 10.1038/ modpathol.2015.4

23. Zhang D, Xu X, Dong Z. PRKCD/PKC $\delta$ contributes to nephrotoxicity during cisplatin chemotherapy by suppressing autophagy. Autophagy. 2017;13(3):631-632. doi: 10.1080/15548627.2016.1269990

24. Bhattarai N, McLinden JH, Xiang J, Mathahs MM, Schmidt WN et al. Hepatitis $\mathrm{C}$ virus infection inhibits a Src-kinase regulatory phosphatase and reduces $\mathrm{T}$ cell activation in vivo. PLoS Pathog. 2017;13(2):e1006232. doi: 10.1371/journal.ppat.1006232

25. Gortzen J, Schierwagen R, Bierwolf J, Klein S, Uschner FE, van der Ven PF, et al. Interplay of matrix stiffness and c-SRC in hepatic fibrosis. Front Physiol. 2017;6:359. doi: 10.3389/fphys.2015.00359

Authors' Contribution: ZR conceived, designed and did manuscript writing along with editing of manuscript. SH did data collection, manuscript writing and editing of manuscript. HS and SS did literature review, manuscript writing, statistical analysis and editing. ZR takes the responsibility and is accountable for all aspects of the work in ensuring that questions related to the accuracy or integrity of any part of the work are appropriately investigated and resolved. 